\title{
PENGARUH PENYERTAAN MODAL VENTURA TERHADAP PENDAPATAN PPU DI PALANGKA RAYA DITINJAU DARI PERSPEKTIF EKONOMI SYARIAH
}

\author{
Nasrullah Hadi \\ Magister Ekonomi Syariah, IAIN Palangka Raya \\ nasrullah.hadi73@gmail.com \\ Ibnu Al Saudi \\ Magister Ekonomi Syariah, IAIN Palangka Raya \\ ibnualsaudi@gmail.com \\ Abdul Syahid \\ Magister Ekonomi Syariah, IAIN Palangka Raya \\ abdul.syahid@iain-palangkaraya.ac.id
}

\begin{abstract}
The existence of venture capital businesses in all provinces was introduced through the Deregulation Package Policy dated 20 December 1988 which was followed by the issuance of Presidential Decree No. 61 of 1988. Although venture capital companies in the regions are referred to as sharia business capital, they bave implemented sharia principles because in their financing, the business partner companies (PPU) that will receive financing do not carry out activities that are probibited according to Islam. The purpose of this study is to analyze the magnitude and prove the effect that venture capital participation affects the income of the business partner company (PPU) in Palangka Raya from a sharia economic perspective. The approach used in this research is a quantitative approach. This research is categorized as an associative study which aims to determine the causal relationship. The results of this study indicate that the variable of venture capital participation has an effect on and increases the income of PPU after receiving venture capital participation.
\end{abstract}

Keywords: Venture Capital, Business Partner Companies, Investments

\begin{abstract}
Abstrak
Keberadaan usaha modal ventura di seluruh provinsi diperkenalkan melalui Kebijakan Paket Deregulasi tanggal 20 Desember 1988 yang diikuti dengan keluarnya Keputusan Presiden No. 61 Tahun 1988.. Meskipun perusahaan modal ventura di daerah meskipun belum bernama modal ventura syariah, namun sudah menjalankan prinsip-prinsip syariah karena dalam pembiayaannya, Perusahaan Pasangan Usaha (PPU) yang akan mendapat pembiayaan tidak melakukan kegiatan yang dilarang menurut Islam. Tujuan penelitian ini untuk menganalisa besarnya dan membuktikan pengaruh bahwa penyertaan modal ventura berpengaruh terhadap pendapatan Perusahaan Pasangan Usaha (PPU) di Palangka Raya ditinjau dari persepktif ekonomi syariah. Pendekatan yang digunakan dalam penelitian ini adalah pendekatan kuantitatif. Penelitian ini dikategorikan sebagai penelitian asosiatif bertujuan untuk mengetahui hubungan yang bersifat sebab akibat. Hasil Penelitian ini menunjukkan bahwa variabel penyertaan modal ventura berpengaruh dan lebih meningkatkan pendapatan PPU setelah menerima penyertaan modal ventura.
\end{abstract}

Kata Kunci: Modal Ventura, Perusahaan Pasangan Usaha , Penyertaan 


\section{Pendahuluan}

Islam memposisikan ekonomi sebagai jalan dan pelengkap khasanah kehidupan manusia untuk mencapai tujuan dan misi yang lebih bermartabat, akhlak yang mulia dan amanah dari peran yang diembannya. Ekonomi menjadi bagian dari sebuah peradaban dalam kehidupan manusia walaupun perekonomian bukan tolak ukur sebuah peradaban yang lebih baik. Ekonomi Islam yang berlandaskan ketuhanan yang terpancar dari akidah ketuhanan yang sengaja Allah turunkan kepada rasul-Nya untuk kemaslahatan manusia (Qaradhawi, 1997). Ekonomi Islam bekerja sekuat tenaga untuk mewujudkan kehidupan yang baik dan sejahtera bagi manusia (Suryani, 2011). Berdasarkan kajian tersebut diatas maka khasanah kehidupan manusia yang berakhlak mulia menjadi bagian peradaban ekonomi yang lebih baik yang berlandaskan ketuhanan untuk kemaslahatan manusia.

Untuk menerapkan ekonomi yang mensejahterakan masyarakat maka pemerintahan Indonesia menerbitkan Peraturan Pemerintah No.18 tahun 1973 untuk membantu pengembangan usaha melalui modal ventura melalui perusahaan perseroan yang membidangi pembiayaan usaha kecil dan menengah di Indonesia diawali dengan didirikannya PT Bahana Pembinaan Usaha Indonesia (BPUI) (Muslim, 2018). Selanjutnya, untuk meningkatkan perkembangan industri modal ventura, pada tahun 1988 usaha modal ventura diperkenalkan secara luas melalui. Keberadaan usaha modal ventura di seluruh provinsi diperkenalkan melalui Kebijakan Paket Deregulasi tanggal 20 Desember 1988 yang diikuti dengan dikeluarkannya Keppres No. 61 tahun 1988. Menurut Undang-Undang No. 10 tahun 1998 tentang Perubahan Atas Undang-Undang No. 7 tahun 1992 tentang perbankan, menyebutkan bahwa lembaga keuangan bank menghimpun dana dari masyarakat dalam bentuk simpanan dan menyalurkannya kepada masyarakat dalam bentuk kredit dan lembaga keuangan dibidang bukan perbankan mengumpulkan dana dari orang pribadi, perusahaan melalui penjualan surat-surat berharga.

Di Indonesia nama Bahana mulai diperhitungan peran sertanya dalam kemajuan percaturan bisnis dibidang keuangan dan banyak juga menginspirasi bisnis keuangan lainnya. BAV merupakan salah satu usahanya dibidang keuangan sebagai pelopor dalam pengembangan usaha mikro, kecil dan menengah di Indonesia yang mempunyai jaringan yang luas terdiri dari 27 perusahaan modal ventura daerah yang merupakan afiliasi PT BAV, dari Aceh hingga Papua dengan didukung oleh sumber daya manusia yang kompeten, loyal dan berpengalaman dan sistem administrasi dan finansial yang terintegrasi dan komprehensif. BPUI menjalankan fungsinya dalam memperkenalkan modal ventura lewat anak usahanya BAV dan kemudian BAV melanjutkan kepada anak usahanya yang tersebar seluruh provinsi di Indonesia lewat perusahaan modal ventura daerah.

Modal ventura fokus kepada UMKM yang layak secara usaha walaupun belum memenuhi kriteria dan persyaratan menurut perbankan. Saat ini modal ventura telah membiayai lima puluh empat ribu mitra UMKM dengan kumulatif pembiayaan hampir Rp 9 triliun yang sekaligus membuka lapangan kerja sekitar 2,1 juta orang (Bahana Artha Ventura, n.d.). Sejak pendiriannya, BAV dan affiliasinya Perusahaan Modal Ventura Daerah (PMVD), terus menjadi yang terdepan dalam usaha percepatan menumbuhkembangkan UMKM melalui modal ventura dan produk lain sesuai dengan pembiayaan pembangunan usaha serta melalui program-program pelatihan (training) dan workshop untuk meningkatkan kinerja mitra usaha (Babana Artha Ventura, n.d.). Strategi yang diterapkan PMVD inilah yang menjadikan modal ventura cepat tersebar di 
kalangan pengusaha UMKM di seluruh wilayah Indonesia karena ada kelebihan yang dimiliki perusahaan modal ventura dan tidak dimilki lembaga keuangan yang lain.

PMVD di Provinsi Kalimantan Tengah berdiri sejak 08 Mei 1997 dengan nama PT. Sarana Kalteng Ventura (SKV). Keberadaan SKV sedikit demi sedikit mulai dikenal masyarakat Kalimantan Tengah umumnya dan khususnya kota Palangka Raya yang merupakan kantor pusat SKV. SKV menjalankan usahanya dengan menggunakan konsep kemitraan terhadap Perusahaan Pasangan Usaha (PPU) (Kalteng Ventura - Beranda, n.d.). Perusahaan yang memperoleh pembiayaan ventura disebut Perusahaan Pasangan Usaha (PPU) atau investee company. Pembiayaan modal ventura mulai dikenal para pengusaha seiring dengan strategi modal ventura melakukan pemasaran dengan mengundang para pengusaha mikro, kecil dan menengah dalam beberapa pertemuan yang diadakan ditempat pertemuan yang mudah didatangi mereka dan menawarkan penyertaan modal ventura yang tujuannya membantu meningkatkan pendapatan usaha mereka dengan sistem pola bagi hasil.

Beberapa cara investasi yang dilakukan oleh modal ventura di Indonesia yaitu dengan cara sebagai berikut:

1. Pembiayaan pola bagi hasil, pembiayaan modal ventura bertujuan mengembangkan usaha PPU dengan konsep bagi hasil dari keuntungan usaha yang dijalankan.

2. Penyertaan saham, penyertaan saham merupakan kerjasama dua pihak atau lebih dalam mengelola usaha bersama-sama untuk memperoleh keuntungan dari usaha tersebut.

3. Obligasi konversi, pembiayaan tidak langsung dengan penghasilan tetap dan apabila usaha mengalami kemajuan maka akan dikonversi menjadi saham.

Modal ventura melakukan penyertaan modal untuk mengembangkan usaha pasangan usaha, dimana perusahaan modal ventura memberikan persyaratan yang lebih mudah dalam hal jaminan dan persyaratan kelengkapan izin usaha dan tidak terlalu banyak persyaratan seperti halnya dalam perbankan. Persyaratan yang mudah kepada PPU yang mengajukan permohonan dana dan PPU mendapat bimbingan dalam membuat laporan keuangan sederhana untuk mengetahui peningkatan pendapatan usahanya.

\section{Metode}

Artikel ini menggunakan jenis penelitian kuantitatif, dan bersifat explanatory survey. Jenis penelitian ini digunakan untuk menjelaskan hasil survei terkait variabel independen dan dependen dengan menampilkan data dalam bentuk numerik dan menganalisisnya. Data yang digunakan pada penelitian ini adalah data primer, dimana data diperoleh langsung dari hasil kuesioner yang diisi oleh responden. Populasi dalam penelitian ini terbatas hanya Perusahaan Pasangan Usaha (PPU) Kallteng Ventura di Palangka Raya dan berkaitan dengan modal ventura yang digunakan untuk modal kerja usahanya dan sumber dana berasal dari program kemitraan bina lingkungan (PKBL) dana lembaga pembiayaan dana bergulir (LPDB) sebanyak 60 orang. Sumber data penelitian ditentukan berdasarkan sampel, teknik sampel accidental sampling yang termasuk teknik nonprobability sampling. Accidental sampling adalah metode penentuan sampel berdasarkan kebetulan. Dan jumlah sampel ditentukan menggunakan rumus Slovin (Bahri, 2018)

Keterangan:

$$
\mathbf{n}=\frac{\mathbf{N}}{1+\mathbf{N} \cdot \mathbf{e}^{2}}
$$

$\mathrm{n}=$ jumlah sampel 
$\mathrm{N}=$ jumlah populasi

$\mathrm{e}=$ tingkat pemahaman sampel, dalam hal ini ditetapkan $10 \%$.

Dengan rumus tersebut, maka akan didapat hasil sebagai berikut:

$$
\begin{gathered}
\mathrm{n}=\frac{60}{1+60.0,05^{2}} \\
\mathrm{n}=\frac{60}{1,15}=52,17 \approx 52
\end{gathered}
$$

Teknik pengumpulan data yang digunakan dalam penelitian ini adalah kuesioner berupa angket dalam penelitian ini memuat pertanyaan-pertanyaan yang berkaitan dengan pendapatan PPU sebelum penyertaan modal ventura dan pendapatan PPU setelah mendapat penyertaan modal ventura tahun 2019 dan dokumentasi metode pengumpulan data melalui sumber data sekunder adalah dokumentasi. Dokumentasi dalam penelitian ini digunakan untuk mengumpulkan data PPU yang mendapat penyertaan modal ventura bersumbur dari dana PKBL dan LPDB di bagian Administrasi Investasi PT. Sarana Kalteng Ventura yang beralamat di Jl. Kinibalu No 266. Analisis data menggunakan analisis regresi linear sederhana, dengan terlebih dahulu melakukan uji validitas reliabilitas, dan asumsi klasik.

\section{Hasil dan Pembahasan Hasil Penelitian \\ Uji Validitas}

Pengujian validitas merupakan analisis terhadap suatu ukuran yang menunjukkan tingkat kevalidan dan kesahilan suatu kuesioner. Uji validitas mengunakan rumus teknik Kolerasi Product Moment. Dasar pengambilan keputusan adalah dinyatakan valid apalabila $r$-hitung $>$ rtabel.

Tabel 1

Uji Validitas Seluruh Instrumen

Correlations

\begin{tabular}{|cc|c|c|c|}
\hline & & Penyertaan_MV & Pendapatan_PU & Total \\
\hline \multirow{4}{*}{ Penyertaan_MV } & Pearson Correlation & 1 &, $676^{* *}$ &, $901^{* *}$ \\
& Sig. (2-tailed) & &, 000 &, 000 \\
& N & 52 & 52 & 52 \\
Pearson Correlation &, $676^{* *}$ & 1 &, $852^{* *}$ \\
Pendapatan_PU & Sig. (2-tailed) &, 000 & &, 000 \\
& N & 52 & 52 & 52 \\
& Pearson Correlation &, $901^{* *}$ &, $852^{* *}$ & 1 \\
Total & Sig. (2-tailed) &, 000 &, 000 & \\
& N & 52 & 52 & 52 \\
\hline
\end{tabular}

**. Correlation is significant at the 0.01 level (2-tailed).

Sumber: Output SPSS versi 20

Hasil pengamatan pada $\mathrm{r}$ tabel didapatkan nilai dari sampel $(\mathrm{N})=52$ sebesar 0.2681 sehingga merujuk pada hasil dari uji validitas dihasilkan bahwa instrumen mulai dari variabel X 
menghasilkan nilai ( $\mathrm{r}$ hitung) $>$ daripada $\mathrm{r}$ tabel. Selain itu variabel Y menghasilkan nilai $\mathrm{r}$ hitung $>$ r tabel. Sehingga dapat disimpulkan bahwa semua instrumen dalam penelitian ini dapat dikatakan valid.

\section{Uji Reliabilitas}

Uji reliabilitas merupakan ukuran suat kestabilan dan konsistensi responden dalam menjawab hal yang berkaitan dengan konstruk-konstruk pertanyaan yang merupakan dimensi suatu variable dan disusun dalam suatu kuesioner. Jika nilai Alpha $>0,60$ maka reliabel (Sujarweni 2015).

Tabel 2

Uji Reliabilitas Instrumen Penelitian

Reliability Statistics

\begin{tabular}{|c|c|}
\hline $\begin{array}{c}\text { Cronbach's } \\
\text { Alpha }\end{array}$ & N of Items \\
\hline, 720 & 2 \\
\hline
\end{tabular}

Sumber: Output SPSS versi 20

Dari hasil uji reliabilitas didapatkan semua nilai dari variabel $\mathrm{X}$ dan $\mathrm{Y}$ menghasilkan nilai Cronbrach's Alpha $>0,720$ Sehingga dapat disimpulkan bahwa semua instrumen dalam penelitian ini reliabel

\section{Uji Normalitas}

Perhitungan uji normalitas menggunakan Uji One-sample Kolmogrov Smirnov Test. Berikut hasil perhitungan menggunakan SPSS.

\section{Tabel 3 Hasil Uji Normalitas}

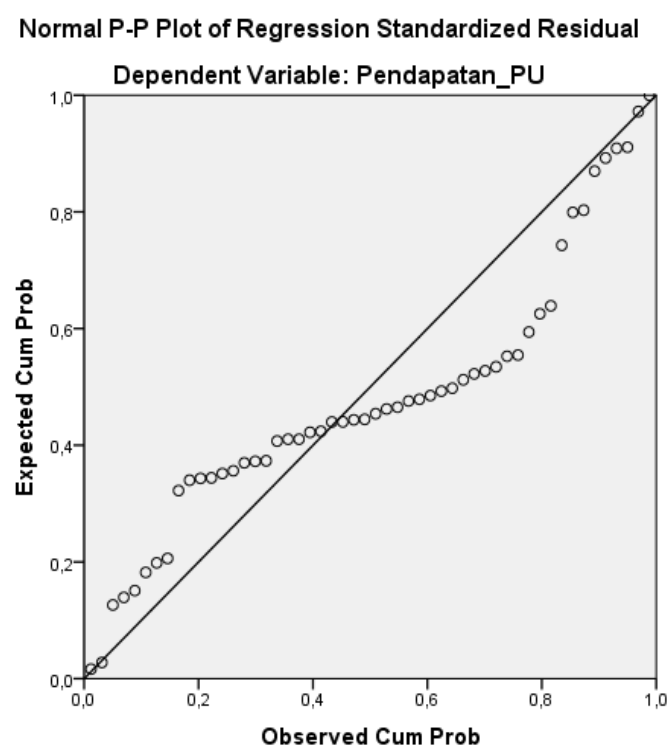

Sumber: Output SPSS versi 20

Jika dilihat dari grafik di atas, data ploting (titik-titik) yang menggambarkan data sesungguhnya mengikuti garis diagonal, maka dapat dikatakan model regresi berdistribusi normal. 


\section{Uji Multikolinearitas}

Uji multikolinearitas digunakan untuk melihat hubungan apakah terjadi korelasi antara variabel penyertaan modal ventura dengan pendapatan PPU, atau dapat dikatakan antar variabel bebas. Dasar pengambilan keputusan diambil dengan nilai tolerance $>0,1$ dan nilai VIF $<10$.

\section{Tabel 4 Uji Multkolinearitas}

Coefficients ${ }^{\mathrm{a}}$

\begin{tabular}{|c|c|c|c|c|c|c|c|}
\hline \multirow[t]{2}{*}{ Model } & \multicolumn{2}{|c|}{ Unstandardized Coefficients } & \multirow{2}{*}{$\begin{array}{c}\text { Standardized } \\
\text { Coefficients } \\
\text { Beta }\end{array}$} & \multirow[t]{2}{*}{$\mathrm{t}$} & \multirow[t]{2}{*}{ Sig. } & \multicolumn{2}{|c|}{$\begin{array}{l}\text { Collinearity } \\
\text { Statistics }\end{array}$} \\
\hline & B & Std. Error & & & & $\begin{array}{c}\text { Tolera } \\
\text { nce }\end{array}$ & VIF \\
\hline $\begin{array}{l}\text { (Constan } \\
\text { t) }\end{array}$ & 22031,921 & & & &, 026 & & \\
\hline PPU &, 145 & ,037 & ,490 & 3,972 & ,000 & 1,000 & 1,000 \\
\hline
\end{tabular}

a. Dependent Variable: MV

Sumber: Output SPSS versi 20

Mengacu pada tabel tersebut, diperoleh hasil penyertaan modal ventura untuk tolerance sebesar $1.000>0,1$ dan nilai VIF sebesar $1.000<10$. Dengan demikian diperoleh kesimpulan, bahwa model regresi ini tidak terjadi multikolinearitas, tidak terjadi hubungan antar variabel independen dan penelitian dapat dilanjutkan.

\section{Uji Heterokedastisitas}

Uji heterokedastisitas digunakan untuk menunjukkan tidak terjadi kesamaan varian. Untuk melihat apakah penelitian ini tidak mengandung heterokedastisitas dengan menggunakan grafik scatterplot.

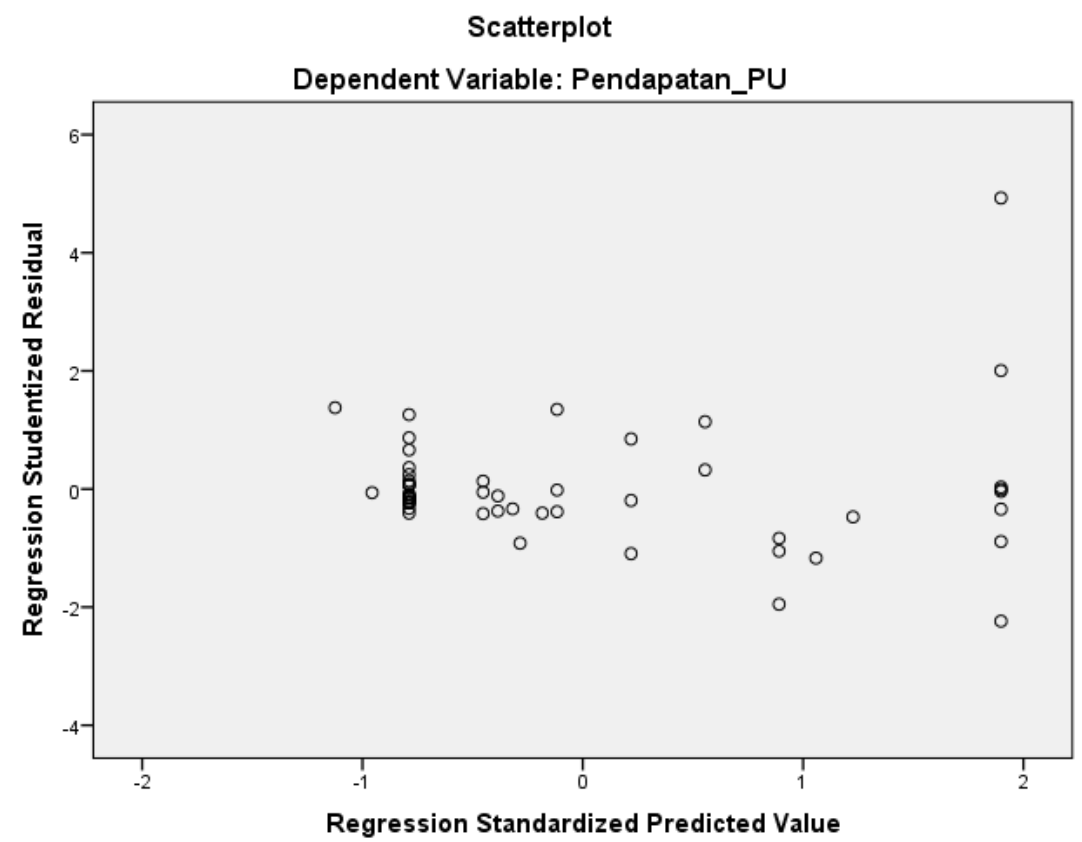

\section{Gambar 1 Hasil Uji Heterokedastisitas}

Sumber: Output SPSS versi 20

Mengacu pada grafik tersebut, diperoleh kesimpulan bahwa data pada penelitian ini terhindar dari heterokedastisitas karena data menyebar secara acak. 


\section{Analisis Regresi Linear}

Analisis data pada penelitian ini menggunakan analisis regresi linear berganda, dimana tujuannya untuk mengetahui pengaruh variabel independen terhadap variabel dependen baik secara parsial maupun simultan. Berikut hasil analisis regresi linear berganda:

Tabel 5 Hasil Uji Regresi Linear Coefficients $^{\mathrm{a}}$

\begin{tabular}{|c|c|c|c|c|c|}
\hline \multirow{2}{*}{ Model } & \multicolumn{2}{|c|}{ Unstandardized Coefficients } & Standardized & \multirow{2}{*}{$\mathrm{T}$} & \multirow{2}{*}{ Sig. } \\
\hline & B & Std. Error & Beta & & \\
\hline $\begin{array}{c}\text { (Constant) } \\
\text { Penyertan_MV }\end{array}$ & $\begin{array}{c}618,207 \\
, 362\end{array}$ & $\begin{array}{c}14680,227 \\
, 056\end{array}$ & ,676 & $\begin{array}{l}, 042 \\
6,485\end{array}$ & $\begin{array}{l}, 967 \\
, 000\end{array}$ \\
\hline
\end{tabular}

a. Dependent Variable: Pendapatan_PU

Sumber: hasil output SPSS versi 20

Merujuk pada hasil statistik menggunakan SPSS dengan Y adalah pendapatan PPU, kemudian $\mathrm{X}$ adalah penyertaan modal ventura, maka persamaan regresi linear yang didapatkan adalah :

$$
\mathrm{Y}=618,207+0,362 \mathrm{X}+\mathrm{e}
$$

Nilai konstanta $(\alpha)=618,207$ dan bersifat positif yang berarti bahwa apabila X tidak dapat memberikan kontribusi $(X=0)$ terhadap $Y$, maka nilai $Y=618,207$. Titik potong garis regresi sederhana berada di sebelah atas dari titik 0, tepatnya di titik 618,207. Adapun nilai koefisien regresi untuk penyertaan modal ventura bernilai positif sebesar 0,362 yang berarti jika nilai penyertaan modal ventura bertambah, maka nilai pendapatan PPU juga akan bertambah sebesar 0,362 .

Diketahui nilai koefisien korelasi (R) sebesar 0,676. Hal tersebut menunjukan seberapa besar hubungan antara variabel dependen dalam hal ini penyertaan modal ventura dengan variabel independen pendapatan PPU. Nilai R sebesar 0,676 menunjukan bahwa variabel penyertaan modal ventura mempunyai pengaruh terhadap pendapatan PPU sebesar 67,6\% sedangkan sisanya dipengaruhi variabel yang lain sebesar $32,4 \%$.

\section{Analisis Korelasi dan Koefisien Determinasi}

Uji korelasi digunakan untuk melihat bagaimana hubungan antara variabel independen dengan variabel depedennya, apakah sangat lemah, lemah, sedang, dan kuat.

Model Summary ${ }^{b}$

\begin{tabular}{|c|c|c|c|c|c|}
\hline Model & $\mathrm{R}$ & $\begin{array}{c}\mathrm{R} \\
\text { Square }\end{array}$ & $\begin{array}{c}\text { Adjusted R } \\
\text { Square }\end{array}$ & $\begin{array}{c}\text { Std. Error of the } \\
\text { Estimate }\end{array}$ & $\begin{array}{c}\text { Durbin- } \\
\text { Watson }\end{array}$ \\
\hline 1 &, $676^{\mathrm{a}}$ &, 457 &, 446 & 59406,46934 & 1,981 \\
\hline
\end{tabular}

a. Predictors: (Constant), Penyertaan_MV

b. Dependent Variable: Pendapatan_PU

Sumber: Data diolah oleh peneliti

Hasil uji statistik di atas menunjukkan bahwa korelasi antara penyertaan modal ventura terhadap pendapatan PPU adalah sebesar 0,676. Angka tersebut berada pada interval 0,6000,799, hal ini berarti penyertaan modal dengan pendapatan PPU memiliki korelasi yang kuat. 
Uji ini digunakan untuk melihat seberapa besar kontribusi yang diberikan oleh variabel independen terhadap variabel dependen. Atau dengan kata lain seberapa besar kemampuan variabel independen mampu menjelaskan pengaruhnya terhadap variabel dependen. Mengacu pada tabel di atas, diperoleh nilai $\mathrm{R}$ Square adalah 0,466. Besarnya nilai tersebut dapat dijelaskan bahwa variabel penyertaan modal ventura terhadap pendapatan PPU dengan nilai 0,466 atau 46,6\% dan sedangkan sisanya sebesar 53,4\% dijelaskan oleh variabel lain di luar penelitian ini.

\section{Uji Hipotesis}

Berdasarkan hasil uji regresi berganda diperoleh hasil uji hipotesis parsial yang ditunjukkan oleh hasil t-test. Uji t bertujuan untuk melihat pengaruh variabel independen terhadap dependen secara parsial. Mengacu pada hasil regresi berganda di atas, diperoleh nilai t-statistic yaitu sebagai berikut:

Hasil t-test yang pertama yaitu pengaruh penyertaan modal ventura terhadap Perusahaan Pasangan Usaha (PPU) berdasarkan pada tabel tersebut diperoleh t-test 6,485 dengan taraf signifikansi 0,000. Hasil ini menunjukkan bahwa nilai signfikansi memenuhi kriteria berpengaruh dimana lebih kecil dari 0,05. Pada penelitian ini 0,000 $<0,05$, sehingga diperoleh bahwa penyertaan modal ventura berpengaruh signifikan terhadap Perusahaan Pasangan Usaha (PPU).

Hipotesis dalam penelitian ini adalah penyertaan modal ventura berpengaruh positif dan signifikan. Berdasarkan Tabel 9 diketahui bahwa nilai koefisien dari penyertaan modal ventura bernilai positif sebesar 0,362 dan nilai t hitung adalah sebesar 6,485 dengan signifikan 0,00 lebih kecil dari 0,05 .

\section{Pembahasan Hasil Penelitian}

Berdasarkan hasil statistik uji regresi sederhana tabel 9 diperoleh $\mathrm{t}$ hitung sebesar 6,485 dengan nilai signifikansi 0,000 , oleh karena nilai signifikansi lebih kecil dari $0,05(0,000<0,05)$ dan Koefisien Determinasi pada tabel 11 mempunyai nilai positif sebesar 0,434 maka hipotesis menyatakan bahwa terdapat pengaruh langsung penyertaan modal ventura $(\mathrm{X})$ terhadap pendapatan PPU (Y) terbukti. Besarnya pengaruh penyertaan modal ventura terhapap pendapatan PPU sebesar 0,457 atau 45,7\% sedangkan sisanya sebesar 54,3\% dipengaruhi oleh faktor lain atau modal usahanya sendiri. Karena hal ini disebabkan oleh penyertaan modal ventura memiliki nilai signifikansi sebesar 0,00 lebih kecil dari 0,05 karena nilai signifikansi lebih kecil dari 5\% maka hipotesis diterima.

Hal ini berarti bahwa variabel penyertaan modal ventura mempengaruhi terhadap pendapatan PPU ditinjau dari perspektif ekonomi syariah secara signifikan. Sehingga dapat dikatakan bahwa hipotesis dapat diterima. Dari penjelasan tersebut dapat dikatakan bahwa keberadaan PT. Sarana Kalteng Ventura yang bermitra dengan PPU di Palangkar Raya saling bersenergi dan bermanfaat dalam meningkatan pendapatan usaha PPU setelah menerima penyertaan modal ventura. Hasil penelitian ini mendukung penelitian yang dilakukan oleh Pikodana (2013), Rosalina (2014) dan Agus Pitoyo (2014) yang menunjukkan pemberian modal usaha meningkatan pendapatan nasabah.

\section{Kesimpulan}

Berdasarkan hasil penelitian dan pembahasan yang telah diuraikan pada bab sebelumnya maka dapat disimpulkan bahwa: Berdasarkan analisis regresi sederhana tabel 9 diperoleh $\mathrm{t}$ 
hitung sebesar 6,485 dengan nilai signifikansi 0,000 , nilai signifikansi lebih kecil dari 0,05 (0,000 $<0,05)$ dapat disimpulkan bahwa penyertaan modal ventura berpengaruh terhadap pendapatan perusahaan pasangan usaha di Palangka Raya. Hasil Uji Koefisien Determinasi dimana kolom R Square 0,457 atau 45,7\% sehingga dapat diartikan bahwa hipotesis Ha yang berarti penyertaan modal ventura berpengaruh terhadap pendapatan perusahaan pasangan usaha di Palangka Raya.

Dari hasil penelitian di atas, maka dapat diberikan rekomendasi Bagi PT. Sarana Kalteng Ventura dapat dijadikan sebagai dasar dalam pengambilan keputusan di masa yang akan datang dengan melihat hasil penelitian ini bahwa penyertaan modal ventura dari Rp. 100.000.000,- s/d Rp.500.000.000,- sangat berpengaruh positif terhadap pendapatan PPU.

\section{Referensi}

Abi Hurairah Moechdie, \& Haryajid Ramelan. (2012). Gerbang Pintar Pasar Modal. Capital Bridge Advisory.

Antonio, M. S. (2003). Bank Syariah: Dari Teori Ke Praktik (Ketujuh). Gema Insani. Arviyan Arifin, V. R. (2010). Islamic Banking. Bumi Aksara.

Bahana Artha Ventura. (n.d.). Retrieved May 8, 2020, from https://www.bahanaventura.com/profil/profil-bav/

Bahri, S. (2018). Metodologi Penelitian Bisnis. CV. Andi Offset.

Kalteng Ventura-Beranda. (n.d.). Retrieved December 1, 2020, from https://www.kaltengventura.co.id/index.php\#about

Kasmir. (2008). Bank Dan Lembaga Keuangan Lainnya. PT. Raja Grafindo Persada.

Manan, A. (2012). Hukum Ekonomi Syariah. Kencana Prenada Media Grup.

Muhamad. (2019). Manajemen Pembiayaan Mudharabah. Remaja Rosdakarya.

Muhammad dkk. (2004). Seri Hukum Lembaga Keuangan Dan Pembiayaan. Citra Aditya Bakti.

Muslim, S. (2018). Modal Ventura Syariah. Pustaka Setia.

Nafik HR, M. (2009). Bursa Efek dan Investasi Syariah. Srambi Ilmu Semesta.

Nurul Huda dkk. (2010). Lembaga Kenangan Islam. Kencana.

Qaradhawi, Y. A. (1997). Norma \& Etika Ekonomi Islam, Terjemahan Zainal Arifin. Gema Insani. Soemitra, A. (2010). Bank Dan Lembaga Keuangan Syariah. Kencana.

Sugiyono. (2018). Metode Penelitian Kuantitatif, Kualitatif, dan R \& D. Alfabeta, CV.

Suryani. (2011). Keadilan Ekonomi Dalam Perspektif Ekonomi Syariah: Sebuah Tinjauan Teori. MAKSIMUM 2, No. 1. 